\title{
Managing potential impacts of reservoir enlargement on threatened Macquaria australasica and Gadopsis bispinosus in southeastern Australia
}

\author{
Mark Lintermans* \\ Institute for Applied Ecology, University of Canberra, Canberra, ACT 2602, Australia
}

\begin{abstract}
Enlargement of a domestic water supply reservoir on the Cotter River in southeastern Australia $(4$ to $78 \mathrm{Gl}$ ) includes an inundation zone that contains 2 threatened fish species, Macquarie perch Macquaria australasica and two-spined blackfish Gadopsis bispinosus. The enlarged reservoir will be $50 \mathrm{~m}$ deeper and impound an additional $4.5 \mathrm{~km}$ of river and thus poses a number of potential threats to these fish species. The majority of threats relate to the inundation zone or upstream environments, as downstream environments have been degraded by significant flow alterations from the existing Cotter Dam and 2 upstream dams. Threats include the loss of refuge habitat and associated increased predation, loss of preferred food sources, invasion and expansion of alien fish populations, loss of spawning habitat (or access to it), and the introduction of disease. To minimise or mitigate these threats, a collaborative and comprehensive research and management program is underway involving participation from the water utility and various universities and government agencies. Funding by the water utility of an independent senior fisheries scientist, establishment of a stakeholder steering group, independent peer review processes, and dedicated staff within the design and construction alliance are intended to ensure fish requirements are considered in dam design, construction, and operation. The establishment of an independent, collaborative science-driven process, coupled with the establishment of a long-term monitoring program in an adaptive management framework is a model for other infrastructure projects worldwide, particularly those that threaten riverine fish.
\end{abstract}

KEY WORDS: Threatened fish · Macquarie perch · Macquaria australasica · Two-spined blackfish · Gadopsis bispinosus $\cdot$ Reservoir $\cdot$ Reservoir impacts

\section{INTRODUCTION}

Freshwater habitats are globally imperilled and the construction and operation of dams is one of the major threats to such systems (Sala et al. 2000, Cowx 2002, Malmqvist \& Rundle 2002, Dudgeon et al. 2006, Helfman 2007, Jelks et al. 2008). Large dams (>15 m in height), numbering $>45000$ globally, affect over half of the world's large river systems (Nilsson et al. 2005) and have major impacts on riverine fish com- munities (Dudgeon et al. 2006, Poff et al. 2007). Dams also convert lotic to lentic habitat with $19 \%$ of the total combined lengths of rivers in the USA drowned by reservoirs (Graf 2001) and a worldwide surface area estimated to be as high as 1.5 million $\mathrm{km}^{2}$ (St. Louis et al. 2000).

Globally, the impacts of dams on aquatic ecosystems have been well documented, with major downstream effects of flow regulation, capture of sediment and organic matter, thermal pollution, and barriers to 
fish migration (Baxter 1977, Nilsson et al. 2005, Poff et al. 2007, Olden \& Naiman 2010). Impacts within the inundation zone include increased greenhouse gas emissions, inundation of terrestrial, riparian and fluvial habitats, sedimentation, decreased water quality (particularly dissolved oxygen and temperature), altered fish community structure (from lotic to lentic dominated), rapid or extreme fluctuations in water level, and invasion or proliferation of alien species (Clavero et al. 2004, Agostinho et al. 2008, Johnson et al. 2008, Gao et al. 2010). Impacts on upstream lotic habitats (aside from loss of migratory species) have been less well reported and include the proliferation of alien species, with aliens using impoundments to establish new populations or as a 'staging post' for further expansion (e.g. Havel et al. 2005, Prenda et al. 2006, TSS 2006). Efforts to mitigate the impacts of dams have largely centred on downstream impacts, such as the provision of fish passage and critical flow elements (e.g. spawning flows or floodplain inundation) (Larinier 2001, King et al. 2009, Poff et al. 2010).

Human population growth has increased demand for secure water supplies worldwide, and predicted changes to rainfall and climate patterns under global climate change scenarios are likely to further increase demand for increased water security (Ficke et al. 2007, Palmer et al. 2008). Competing demands for water have already led to increased conflict over human and ecosystem uses (Poff et al. 2003) with such conflict likely to increase. In southeast Australia climate change predictions of increased temperature, higher evapotranspiration, and changed rainfall and runoff patterns are likely to result in an increased desire to harvest and manage water more intensively (CSIRO \& Bureau of Meteorology 2007).

In Australia the recent millennium drought (Bond et al. 2008) has focussed attention on dwindling agricultural and urban water supplies and prompted interest in a range of infrastructure solutions (dams and pipelines) to address possible future water shortages. The threats to Australian freshwater fish are similar to those internationally (Cadwallader 1978, Allen et al. 2002, Lintermans 2007), and, as the most arid inhabited continent, the effects of water abstraction, diversion, and storage have become increasingly apparent. The Murray-Darling Basin (MDB) in southeastern Australia contributes 39\% of the nation's agricultural production and accounts for $50 \%$ of the nation's irrigated agricultural water use from 2007 to 2008 (MDBA 2010). The high incidence of weirs, dams, and direct water extraction has resulted in significant degradation of riverine ecosys- tems (Davies et al. 2010, Koehn \& Lintermans in press), with 23 of the 44 naturally occurring native fish species in the MDB listed as threatened in either state or national listings (Lintermans 2007, Koehn \& Lintermans in press).

The enlargement or refurbishment of dams provides an opportunity to re-evaluate threats and reduce adverse impacts to freshwater ecosystems posed by individual dams and improve their environmental performance (Pittock \& Hartmann 2011). The Australian Capital Territory (ACT) lies wholly within the MDB, and is the largest urban centre in the MDB, with the population of Canberra at approximately 360000 . In response to drought-induced water shortages, forecast population growth and a predicted long-term outlook of an almost $50 \%$ decline in catchment inflows, the enlargement of a domestic water supply dam on the lower Cotter River has commenced.

Much of the literature on the impacts of dams on fishes focuses on downstream impacts, such as alteration to flow regimes, coldwater pollution, or barriers to upstream migration posed by the dam wall (Gehrke et al. 2002, Poff et al. 2007, Sherman et al. 2007). The major focus for the impacts of enlargement of Cotter Reservoir differed, as the downstream environment was already significantly degraded by the existing Cotter Dam and 2 upstream reservoirs. Remediation of the barrier to fish passage posed by the existing dam is not desirable, as the dam prevents upstream invasion by alien fish species. The 2 focal species (Macquarie perch Macquaria australasica and two-spined blackfish Gadopsis bispinosus) are effectively extinct in the Cotter River downstream of the existing reservoir. Hence there is concern for these species within and upstream of the proposed impoundment. Macquarie perch have only occasionally been captured in the river downstream since the mid-1980s, and these fish are presumed to have been displaced from the upstream reservoir. Two-spined blackfish were last recorded in the river downstream in the early 1960s (Lintermans 1998).

The present study outlines the major threats and associated knowledge gaps relating to the Cotter Reservoir enlargement. In particular, the present study describes the research and mitigation program designed to respond to these threats, and also the integrated management process employed to collect the required scientific knowledge and to manage threats. Lessons learned from this process should be relevant to those dealing with the installation of hydropower or domestic water supply dams or other water infrastructures around the globe. 


\section{STUDY AREA}

\section{Physical description}

The Cotter River is approximately $74 \mathrm{~km}$ long and drains a forested montane catchment of $482 \mathrm{~km}^{2}$, which has been managed to protect water quality since the early 1900s (Nichols et al. 2006). Most of the Cotter catchment (88\%) lies within Namadgi National Park, where the vegetation is primarily native sclerophyll forest. Average annual rainfall (1936 to 1993) in the catchment is $980 \mathrm{~mm}$ (Maddock et al. 2004), with the temperate climate characterised by cold winters (monthly mean minimum and maximum temperatures of 0.2 and $12.7^{\circ} \mathrm{C}$, respectively) and hot summers (monthly mean minimum and maximum temperatures of 10.8 and $27.2^{\circ} \mathrm{C}$, respectively) (BOM 2011). The lower catchment contains a small area (4200 ha) of softwood plantation forestry, although this land use is being phased out. The river is an upland boulder-, cobble-, and gravel-bed stream (Maddock et al. 2004), largely in a natural physical condition, apart from containing 3 reservoirs, with the oldest and smallest (Cotter Reservoir) located downstream of Corin and Bendora Reservoirs (Fig. 1). Cotter Reservoir was initially completed in 1915 and enlarged in 1951 to provide the present storage capacity of approximately 4 GL. Subsequent construction of Bendora Reservoir in 1961 and Corin Reservoir in 1968 meant that Cotter Reservoir had been largely unused for water supply since the 1970s. A severe bushfire burnt nearly $100 \%$ of the catchment in 2003, significantly impacting water quality and requiring the construction of a new water treatment facility (Carey et al. 2003, ACTEW Corporation 2009). Since early 2005 Cotter Reservoir has consequently returned to being an active part of the Canberra water supply.

In 2004 it was determined that the existing water supply capacity would not meet Canberra's water needs in light of projected population growth, and planning commenced to identify additional water supply options. From an initial list of 30 infrastructure options, the enlargement of Cotter Reservoir to a capacity of 78 GL was selected based on its relative economic and social benefit to the community, reliability of large-scale water supply and manageable environmental impacts (ACTEW Corporation 2009). Planning and design work commenced in late 2007, with construction to be completed by 2012 . The new dam wall will be $80 \mathrm{~m}$ high, with the enlarged reservoir covering $280 \mathrm{Ha}$, and inundating approximately $7.6 \mathrm{~km}$ of river. The existing dam is $30 \mathrm{~m}$ high, and

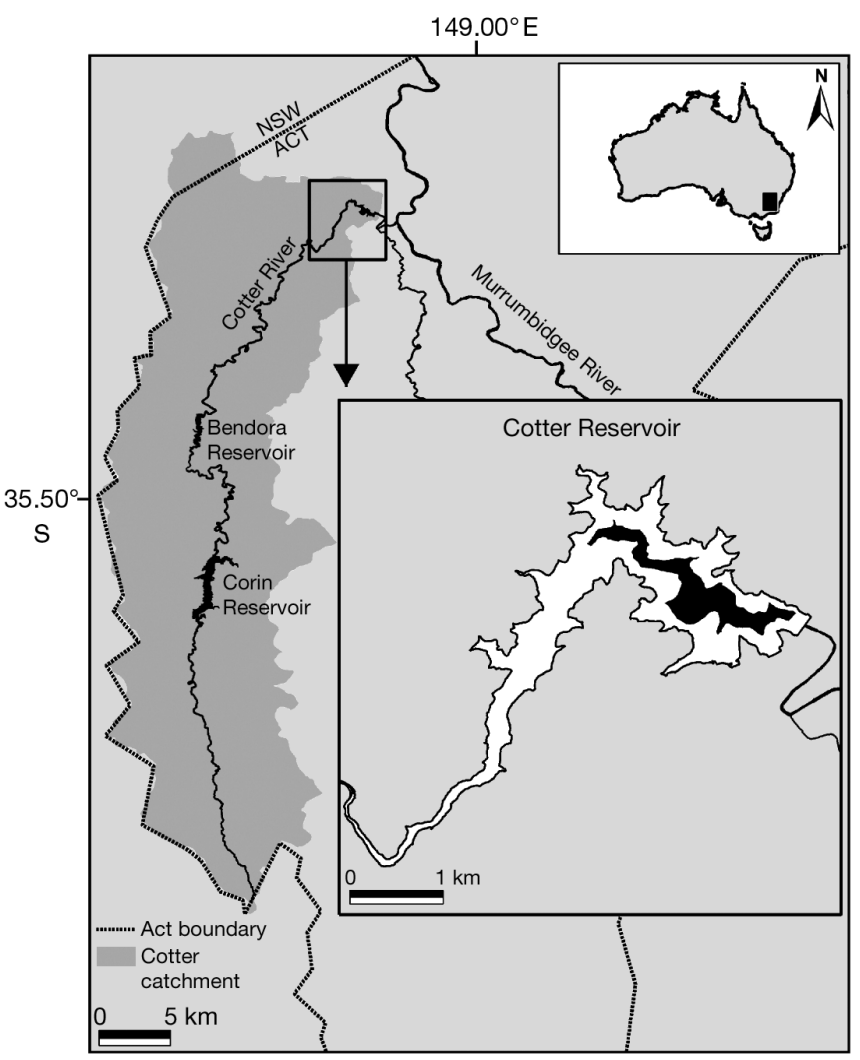

Fig. 1. Location of the Cotter River catchment (dark grey) in the Australian Capital Territory (ACT) showing the 3 reservoirs. The large inset shows the extent of the projected Cotter Reservoir enlargement compared to the current extent of the existing reservoir (black)

the current reservoir covers 40 Ha and is $3.1 \mathrm{~km}$ long. For structural and heritage reasons, the new dam wall will be constructed approximately $125 \mathrm{~m}$ downstream of the existing wall, which will be submerged under the enlarged reservoir (ACTEW Corporation 2009).

\section{Fish fauna}

The Cotter River contains 4 threatened fish or crayfish species: Macquarie perch Macquaria australasica, two-spined blackfish Gadopsis bispinosus, Murray River crayfish Euastacus armatus and a stocked population of trout cod Maccullochella macquariensis (Lintermans 2002, 2007). Both Macquarie perch and trout cod are listed as endangered nationally under the Environment Protection and Biodiversity Conservation (EPBC) Act 1999 (Lintermans 2007) and locally under the ACT Nature Conservation (NCA) Act 1980. Two-spined blackfish and Murray River crayfish are listed as vulnerable under the NCA 
(ACT Government 2007). All 4 species are essentially riverine species, but in the Cotter catchment all 3 fish maintain populations in some or all of the reservoirs (Corin, Bendora, and Cotter), with the status of Murray River crayfish uncertain. Trout cod are largely found in Bendora Reservoir (the stocking site), with only isolated individuals recorded downstream (author's unpubl. data) and so are not further considered in the present study. Murray River crayfish have been reliably recorded only once in Cotter Reservoir (in 2009) and occasionally in the Cotter River, immediately upstream (author's unpubl. data). It is unknown whether these represent translocated individuals (a common practice by recreational fisherman) or remnants of a natural population. Murray River crayfish are still present downstream of Cotter Dam in the Cotter and Murrumbidgee Rivers (Lintermans \& Rutzou 1991). Two-spined blackfish are abundant along most of the river and in the 2 upstream reservoirs. However, they are absent from Cotter Reservoir and the river downstream, largely as a result of historic sedimentation from forestry activities in the lower catchment (Lintermans 2002). Macquarie perch were previously more widely distributed along the lower reaches of the Cotter River (below Bendora Reservoir), but their range has declined since the 1970s to be largely centred on Cotter Reservoir and the $6 \mathrm{~km}$ of river immediately upstream (Lintermans 2002, ACT Government 2007).

There are a number of alien fish species established in the Cotter catchment, two of which are centred in the Cotter Reservoir (eastern gambusia Gambusia holbrooki and goldfish Carassius auratus), one expanding upstream from Cotter Reservoir (oriental weatherloach Misgurnus anguillicaudatus), one restricted to the lower catchment, downstream of Bendora Dam (brown trout Salmo trutta), and one widespread throughout the catchment (rainbow trout Oncorhynchus mykiss) (Lintermans 2002). Two additional alien species are present in the final $2 \mathrm{~km}$ of the Cotter River above its confluence with the Murrumbidgee River (common carp Cyprinus carpio, redfin perch Perca fluviatilis), but they are excluded from upstream passage by the Cotter Dam wall (Lintermans 2002).

Macquarie perch have 2 morphologically distinct and geographically disjunct forms, which are likely to be separate taxa (Faulks et al. 2010). Only the Murray-Darling (western) taxon is present in the $\mathrm{ACT}$, and it is a moderately sized, deep-bodied percichthyid attaining a maximum weight of $3.5 \mathrm{~kg}$ and $550 \mathrm{~mm}$ total length (TL). Fish larger than $1 \mathrm{~kg}$ and $350 \mathrm{~mm}$ TL are rare (Lintermans 2007, Lintermans \&
Ebner 2010). Macquarie perch can form significant populations in impoundments, but are truly a riverine fish that can only breed in flowing waters (Cadwallader \& Rogan 1977, Lintermans 2007). Spawning occurs at the foot of pools, and adhesive demersal fertilised eggs are then lodged in downstream riffles (Wharton 1968, Douglas 2002, Tonkin et al. 2010). In Cotter Reservoir, Macquarie perch adults are largely reliant on fringing macrophytes (predominantly Phragmites australis and Typha domingensis) for daytime shelter, with a substantial band of macrophytes established in the upper half of the reservoir (Ebner et al. 2011). Adults migrate upstream out of the reservoir to the adjacent pools and riffles in the inflowing river to spawn, with spawning commonly occurring in the first $500 \mathrm{~m}$ upstream of the reservoir (Ebner \& Lintermans 2007). Cotter Reservoir contains the last viable population of this species in the ACT, with recent estimates of mean effective population size ranging from 17 to 79 fish (Farrington et al. 2009).

Two-spined blackfish is a small, sturdy, elongate fish (maximum size $\sim 350 \mathrm{~mm}$ and $200 \mathrm{~g}$ ) that is largely restricted to upland rocky-bottomed streams in the southern MDB, generally with intact catchment vegetation and low sedimentation (Koehn 1990, Lintermans 2007). It is generally abundant where present, though some declines in range and isolation of populations have occurred post-European settlement (Morris et al. 2001, ACT Government 2007). Two-spined blackfish deposit large ( $3.5 \mathrm{~mm}$ diameter), adhesive eggs onto the upper surface of cobbles, with males displaying extended parental care (Lintermans 1998, 2007, O'Connor \& Zampatti 2006). This species has a restricted home range, generally $<25 \mathrm{~m}$, and is nocturnal (Lintermans 1998, Broadhurst et al. 2011).

It was recognised early on that the threatened fish in the Cotter River catchment were a key consideration in whether construction and operation of the enlarged reservoir could proceed. The provisions of the EPBC Act require that activities that could have significant detrimental impacts on nationally listed species (e.g. Macquarie perch and trout cod) require approval from the federal government, in this case following the preparation of a Public Environment Report (ACTEW Corporation 2009). As Macquarie perch and two-spined blackfish are also covered by the NCA, approval of activities that might adversely affect these species was also required under this legislation. In addition, approvals were also necessary under the ACT Planning and Development Act 2007, requiring the preparation of an Environmental Impact Statement (ACTEW Corporation 2009). 


\section{Potential threats}

A range of potential threats exists to populations of Macquarie perch and two-spined blackfish from the enlarged reservoir. The major threats can be summarised as:

- Loss of refuge habitat

- Impacts of predators (brown trout Salmo trutta, rainbow trout Oncorhynchus mykiss and cormorants Phalacrocorax spp.)

- Invasion/expansion of alien fish populations

- Loss of spawning habitat (or access to it)

- Loss of food resources

- Diseases

Adult Macquarie perch in Cotter Reservoir were known to rely on fringing emergent macrophytes for daytime shelter, presumably from diurnal avian predators (cormorants) (Ebner \& Lintermans 2007). These macrophyte beds had established as a result of the reservoir being almost constantly full since the 1970s, following its discontinued use as a domestic water supply. The substrate of the reservoir is highly silted as a result of forestry activities in the catchment, and the macrophytes provide the only substantial long-term cover for adult fish. There has been a temporary increase in cover for adult fish following large bushfires in 2003 that killed riparian softwood plantations and contributed large amounts of fallen burnt pine into the reservoir; however, this timber is expected to rapidly decay. The reservoir enlargement will submerge the existing macrophytes under $50 \mathrm{~m}$ of water, and the proposed operating regime for the enlarged reservoir will result in unstable water levels, making reestablishment of macrophytes unlikely (ACTEW Corporation 2009).

Loss of fringing macrophyte beds may also result in a loss of a primary food resource for adult Macquarie perch. The diet of riverine populations of Macquarie perch in the Canberra region is dominated by decapods such as shrimp Paratya australiensis and freshwater prawn Macrobrachium australiense (Lintermans 2006), with these large prey items likely to be an important energy source for adult fish. It is thought that the existing macrophyte beds are the major source of these decapods and that the proposed operating regime and frequency of drawdown in the enlarged reservoir will compromise this food supply in the long term.

The major predators of adult and sub-adult Macquarie perch are likely to be cormorants, particularly the great cormorant Phalocrocarax carbo, with predation on adult Macquarie perch previously recorded in the reservoir (Ebner \& Lintermans 2007). The trophic upsurge following inundation of new terrestrial habitats is well documented for reservoirs worldwide (Kimmel \& Groeger 1986, Popp et al. 1996, Gunkel et al. 2003) and can persist for more than a decade (e.g. Gunkel et al. 2003). Trophic upsurge results from the release of nutrients from soil or inundated vegetation, which drives increases in phytoplankton, then zooplankton and usually fish populations (Kimmel \& Groeger 1986, Popp et al. 1996). Trophic upsurge in the enlarged Cotter Reservoir is likely to result in a significant increase in fish species such as goldfish, a common dietary item of cormorants in southeastern Australia (McKeown 1944, Miller 1979). An increase in cormorant abundance facilitated by increased abundance of prey species such as goldfish could have significant impacts on the Macquarie perch population, even if cormorant predation on Macquarie perch is incidental. An increase in Macquarie perch abundance from trophic upsurge is also likely, as has occurred in other impoundments in Australia (Cadwallader 1986); however, the increased abundance is temporary with the species known to decline rapidly, often to extinction, as reservoirs age (Cadwallader \& Rogan 1977, Lintermans 2007). It is unknown why reservoir populations of Macquarie perch subsequently decline or disappear after initial increases, and whether single threats, or multiple threats acting synergistically, drive such declines.

Both rainbow trout and brown trout attain large size in the reservoir, are piscivorous, are known to prey on threatened fish worldwide (Cadwallader 1996, Cambray 2003, McDowall 2006, Halverson 2010) and are certainly capable of preying on both threatened fish species in the reservoir and inflowing river. As above, a trophic upsurge resulting in increased goldfish abundance could facilitate an increase in the size of the reservoir trout population, as goldfish are the staple diet of trout in Cotter Reservoir (Ebner et al. 2007). The thermal refuge from high summer water temperatures provided by a deeper reservoir will also be advantageous to trout. Increased abundance of larger trout individuals is also likely to be a consequence of improved food supplies (Wootton 1998), with larger trout capable of and energetically more likely to consume larger prey with greater energy density (e.g. fish) (Ebner et al. 2007, Juncos et al. 2011). Trout must leave the reservoir to spawn, and a spawning run of larger, more abundant trout into the river upstream of the reservoir could have significant predatory impacts on riverine populations of both threatened fish species.

The existing dam wall currently provides a barrier to invasion of the reservoir and catchment upstream 
by carp and redfin perch (Lintermans 2002, ACT Government 2007), making the Cotter River a rare example of a river in the MDB without these 2 species (Lintermans 2007). Redfin perch are the vector and major host for the epizootic haematopoietic necrosis virus (EHNV), a disease of major concern in the MDB (Langdon et al. 1986, Langdon \& Humphrey 1987, Lintermans 2007). Macquarie perch are one of a range of native fish susceptible to EHNV, with laboratory trials demonstrating mortality of all exposed individuals (Langdon 1989). EHNV has been recorded from most moderate to large impoundments in the Canberra region (Whittington et al. 1996), with the virus apparently endemic to the upper Murrumbidgee River catchment (Whittington et al. 2010). Both carp and redfin perch are present in the stilling pond immediately downstream of the existing dam, and the entrapment of these species between the old and new dams would allow them (and potentially EHNV) to colonise the enlarged reservoir.

Both Macquarie perch and two-spined blackfish are known to spawn in the river reach to be inundated by the enlarged reservoir. Macquarie perch are not capable of reproducing in lentic environments; consequently, barriers that prevent movement from lentic to lotic environments could prevent Macquarie perch reproduction and lead to the loss of local populations. The Cotter River in and immediately above the inundation zone of the enlarged reservoir has a relatively steep gradient and contains a number of small, natural potential barriers such as cascades and fast-flowing water over shallow rock bars. The number and behaviour of these barriers at different discharges and their potential to impede upstream movement by Macquarie perch is unknown. Some of these barriers would be inundated when the reservoir is full, but at various reservoir drawdown levels they may still be problematic. In the Queanbeyan River in the Canberra region, construction of the Googong Reservoir impounded the river up to an impassable natural barrier, denying access to riverine spawning sites and resulting in the loss of the reservoir Macquarie perch population (Lintermans 2006). Similarly, a natural instream barrier has been shown to limit access to spawning beds by Macquarie perch in the Mitta Mitta River (Tonkin et al. 2010). Two-spined blackfish do not occur in the existing Cotter Reservoir, as sedimentation has smothered potential spawning sites. While the species is present immediately upstream of the current reservoir, inundation could destroy or compromise spawning habitat as the sediment deposition zone for the enlarged reservoir is transferred to this area.

\section{MANAGEMENT ASPECTS}

\section{Risk assessment}

Threats to fish can be broadly considered under 4 phases of the expansion of the reservoir: planning \& design, construction, filling and operational, with not all threats relevant in all phases (Fig. 2). At the commencement of each phase of the reservoir enlargement all threats will be subject to a qualitative risk assessment process that considers a 5-level scale for both likelihood and consequence. Remedial actions for each significant risk are suggested, with risk then reviewed and reassessed for the next risk assessment. Risk assessments for the first 2 phases (planning \& design, construction) have been completed, with a total of 18 risks assessed in the planning and design phase with an initial risk rating higher than negligible (Table 1). Risk was assessed for each potential threat with and without mitigation options, and then after the knowledge from the research projects was gathered (Table 1). The initial risk ratings reflect high uncertainty in the assessment of some threats, with risk decreasing as knowledge improved as a result of research projects or mitigation activities. For example, the risk of loss of the Macquarie perch population through destruction of fringing macrophytes (Threat 1; Table 1) was initially assessed as very high, reducing to high after mitigation (provision of constructed replacement habitat) (Table 1). This residual rating of high was because it was uncertain whether the species would use constructed habitats; however, results from a research project have reduced this uncertainty, and so the risk was subsequently downgraded to medium (Table 1).

After identification and risk assessment of threats, 35 key knowledge gaps relevant to Macquarie perch and two-spined blackfish in and around the existing reservoir were identified and reviewed, with 17 being of particular relevance to the dam's enlargement (Table 2). While all of the knowledge gaps are relevant to the reservoir and the lower Cotter River catchment, some are general knowledge needs for threatened species management, rather than specific needs associated with the construction of the enlarged reservoir. Along with risk assessment, these knowledge gaps were used to develop a research program that could reduce uncertainty, further inform risk and assist in development of mitigation actions. 


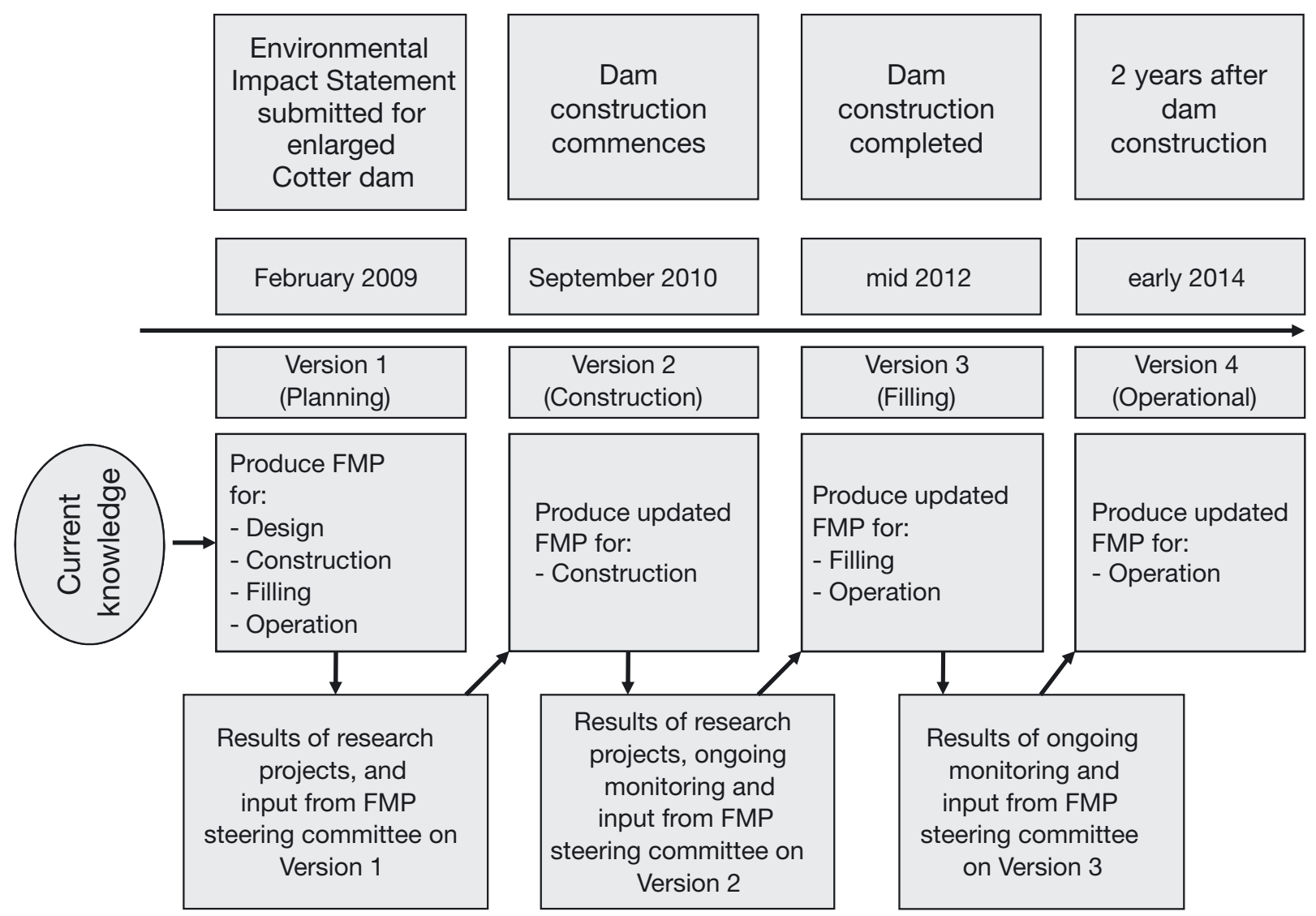

Fig. 2. Timelines and process for completing fish management plans (FMPs) (modified from Nagy et al. 2008)

\section{Mitigating threats and addressing knowledge gaps}

Thirteen research projects (across 7 organisations) were commenced (Table 3) to further mitigation measures to reduce potential threats and to address critical knowledge gaps (Bulk Water Alliance 2010). Twelve of the 13 projects have been completed to date, with 1 project-a long-term monitoring program on the potential impacts of the reservoir enlargement - still ongoing.

The major research project investigated whether adult Macquarie perch would use constructed habitat and which constructed habitat type was preferred. Three habitat designs were investigated and, as a result, approximately $8 \mathrm{~km}$ of linear, rocky reef habitat is being constructed within the inundation zone of the enlarged reservoir (Fig. 3). The placement of constructed habitat in the top $23 \mathrm{~m}$ below full supply level has been informed by modelling of the likely drawdown frequency of the enlarged reservoir, along with ecological knowledge of the diel movement patterns of adult Macquarie perch (Lintermans et al. 2010). This project also characterised the timing of Macquarie perch spawning migrations from the reservoir to the river, and investigated whether twospined blackfish populations in reservoirs resulted from local or upstream spawning.

Two approaches for identifying the impacts of cormorant predation on Macquarie perch have been pursued: a risk-based approach investigating seasonal movements of predator and prey and a pilot diet study characterising direct predation by cormorants of Macquarie perch (Ryan 2010, Lintermans et al. 2011).

Investigations into the swimming performance of Macquarie perch (Starrs 2009, Starrs et al. 2009, 2011) and alien fish species are informing the design of fishways for this species, as well as assisting in the identification of likely in-stream barriers that require management action (Hugh 2010). Knowing the location of barriers within the inundation zone will allow for sensitive management of reservoir water levels during the spawning season to minimise adverse impacts.

A range of susceptible fish species have been tested for EHNV, with no evidence that EHNV is present in 
Table 1. Potential threats from enlargement of the Cotter Reservoir (Australian Capital Territory), project phase (P: planning; C: construction; F: filling; O: operational), species affected (Mp: Macquarie perch Macquaria australasica; 2spB: two-spined blackfish Gadopsis bispinosus) and how risk rating (VH: very high; H: high; M: medium; L: low; N: negligible) has altered after consideration of mitigation activities and as knowledge has improved between Fish Management Plan Version 1 (FMP V1) and Version 2 (FMP V2). Where the risk varies between species this is indicated; otherwise, risk rating applies to both species. FMP V1 initial (init.) risk rating excludes mitigation options, and FMP V1 residual (res.) risk is that remaining following mitigation actions. FMP V2 risk rating is the updated and the current risk assessment. Potential threats with an initial risk rating of negligible have been excluded. EHNV: epizootic haematopoietic necrosis virus

\begin{tabular}{|c|c|c|c|c|c|c|}
\hline \multirow{2}{*}{$\begin{array}{l}\text { Threat } \\
\text { no. }\end{array}$} & \multirow{2}{*}{ Potential threat } & \multirow{2}{*}{$\begin{array}{c}\text { Project } \\
\text { phase }\end{array}$} & \multirow{2}{*}{$\begin{array}{l}\text { Species } \\
\text { affected }\end{array}$} & \multicolumn{3}{|c|}{ — Risk rating } \\
\hline & & & & $\begin{array}{l}\text { FMP } \\
\text { Init. }\end{array}$ & $\begin{array}{l}\text { V1 } \\
\text { Res. }\end{array}$ & FMP V2 \\
\hline 1 & $\begin{array}{l}\text { Decline or loss of fish population through loss of } \\
\text { emergent macrophyte habitat that provides } \\
\text { adult shelter }\end{array}$ & $\mathrm{F}, \mathrm{O}$ & $\mathrm{Mp}$ & $\mathrm{VH}$ & $\mathrm{H}$ & M \\
\hline 2 & $\begin{array}{l}\text { Increase in cormorant predation via increased } \\
\text { cormorant abundance during trophic upsurge }\end{array}$ & $\mathrm{F}, \mathrm{O}$ & $\mathrm{Mp}$ & $\mathrm{VH}$ & $\mathrm{H}$ & $\mathrm{M}$ \\
\hline 3 & $\begin{array}{l}\text { Reduced access to spawning sites past natural } \\
\text { barriers in river }\end{array}$ & $\mathrm{F}, \mathrm{O}$ & $\mathrm{Mp}$ & $\mathrm{VH}$ & $\mathrm{H}$ & M \\
\hline 4 & $\begin{array}{l}\text { Coldwater discharges from Bendora Reservoir } \\
\text { affecting spawning success }\end{array}$ & $\mathrm{O}$ & $\mathrm{Mp}, 2 \mathrm{spB}$ & $\mathrm{H}$ & M & $\mathrm{L}$ \\
\hline 5 & $\begin{array}{l}\text { Short-term degradation from fuel or oil spills or } \\
\text { other contaminants }\end{array}$ & $\mathrm{C}$ & $\mathrm{Mp}$ & $\mathrm{H}$ & M & $\mathrm{L}$ \\
\hline 6 & $\begin{array}{l}\text { Reduction in threatened fish populations from } \\
\text { invasion of alien carp and redfin perch during } \\
\text { construction }\end{array}$ & $\mathrm{C}$ & $\mathrm{Mp}, 2 \mathrm{spB}$ & $\mathrm{VH}$ & $\mathrm{H}$ & $\begin{array}{l}\text { L (Mp), } \\
\mathrm{L}(2 \mathrm{spB})\end{array}$ \\
\hline 7 & Entrainment of adult fish in offtake structures & $\mathrm{O}$ & $\mathrm{Mp}, 2 \mathrm{spB}$ & $\mathrm{M}$ & $\mathrm{M}$ & $\mathrm{N}$ \\
\hline 8 & $\begin{array}{l}\text { Introduction of EHNV and redfin perch during } \\
\text { construction }\end{array}$ & $\mathrm{C}$ & $\mathrm{Mp}, 2 \mathrm{spB}$ & $\mathrm{VH}$ & $\mathrm{H}$ & $\begin{array}{l}\text { M (Mp) } \\
\mathrm{L}(2 \mathrm{spB})\end{array}$ \\
\hline 9 & $\begin{array}{l}\text { Failure to detect long-term }(10-20 \mathrm{yr}) \text { decline } \\
\text { following initial trophic upsurge }\end{array}$ & $\mathrm{O}$ & $\mathrm{Mp}, 2 \mathrm{spB}$ & $\mathrm{VH}$ & $\mathrm{H}$ & $\begin{array}{l}\mathrm{M}(\mathrm{Mp}) \\
\mathrm{N}(2 \mathrm{spB})\end{array}$ \\
\hline 10 & $\begin{array}{l}\text { Decline of Macquarie perch following loss } \\
\text { of spawning areas in Cotter River }\end{array}$ & $\mathrm{F}, \mathrm{O}$ & $\mathrm{Mp}$ & $\mathrm{VH}$ & M & $\mathrm{M}$ \\
\hline 11 & $\begin{array}{l}\text { Increased abundance of existing alien fish } \\
\text { resulting in decline of threatened fish }\end{array}$ & $\mathrm{F}, \mathrm{O}$ & $\mathrm{Mp}, 2 \mathrm{spB}$ & $\mathrm{VH}$ & $\mathrm{H}$ & $\begin{array}{l}\text { M (Mp) } \\
\mathrm{L}(2 \mathrm{spB})\end{array}$ \\
\hline 12 & $\begin{array}{l}\text { Loss of critical food resources as a result of } \\
\text { loss of emergent macrophytes }\end{array}$ & $\mathrm{F}, \mathrm{O}$ & $\mathrm{Mp}$ & $\mathrm{VH}$ & $\mathrm{H}$ & M \\
\hline 13 & $\begin{array}{l}\text { Short-term reduction in fish population from } \\
\text { increased particulates in aquatic environment }\end{array}$ & $\mathrm{C}$ & $\mathrm{Mp}, 2 \mathrm{spB}$ & $\mathrm{H}$ & $\mathrm{M}$ & $\mathrm{N}$ \\
\hline 14 & $\begin{array}{l}\text { Fluctuating water levels in reservoir desiccate } \\
\text { two-spined blackfish eggs }\end{array}$ & $\mathrm{F}, \mathrm{O}$ & $2 \mathrm{spB}$ & $\mathrm{L}^{\mathrm{a}, \mathrm{b}}$ & & $\mathrm{N}$ \\
\hline 15 & $\begin{array}{l}\text { Habitat loss as a result of impoundment }(\mathrm{Mp}) \text { or sedi- } \\
\text { mentation }(2 \mathrm{spB}) \text { of newly inundated areas of river }\end{array}$ & $\mathrm{F}, \mathrm{O}$ & $\mathrm{Mp}, 2 \mathrm{spB}$ & $\mathrm{VH}$ & $\mathrm{H}$ & $\mathrm{N}$ \\
\hline 16 & $\begin{array}{l}\text { Short-term oxygen depletion following rapid } \\
\text { inundation of terrestrial vegetation }\end{array}$ & $\mathrm{F}$ & $\mathrm{Mp}$ & $M^{b, d}$ & & M \\
\hline 17 & $\begin{array}{l}\text { Long-term decline in Macquarie perch as a result } \\
\text { of inappropriate design of replacement habitat }\end{array}$ & $\mathrm{P}, \mathrm{F}, \mathrm{O}$ & $\mathrm{Mp}$ & $\mathrm{H}$ & $\mathrm{M}$ & $\mathrm{L}$ \\
\hline 18 & $\begin{array}{l}\text { Long-term oxygen depletion at increased depth } \\
\text { as a result of stratification of reservoir }\end{array}$ & $\mathrm{F}, \mathrm{O}$ & $\mathrm{Mp}, 2 \mathrm{spB}$ & $\mathrm{VH}$ & M & $\mathrm{L}$ \\
\hline
\end{tabular}

the Cotter Reservoir or upstream (Whittington 2008). This has resulted in stringent measures to disinfect the riverbed between the old and new dam walls. In conjunction with disinfection measures, eradication of alien carp and redfin perch has also been completed between the 2 dam walls, using physical removal of fish followed by chemical treatment.
To reduce risk of the loss of the only Macquarie perch population in the ACT, a translocation program from the existing Cotter Reservoir has commenced, with a view to establishing at least 1 additional Macquarie perch population outside of the lower Cotter catchment. Translocation efforts are guided by an age-structured population model 
Table 2. Significant knowledge gaps for Macquarie perch Macquaria australasica (Mp) and two-spined blackfish Gadopsis bispinosus (2spB) in the vicinity of Cotter Reservoir (amended from Nagy et al. 2008). EHNV: epizootic haematopoietic necrosis virus

\begin{tabular}{|c|c|}
\hline Knowledge gap & Relevant spec \\
\hline Movement requirements (timing, extent, cues) for different life-stages (larval, juvenile, sub-adult, adult) & $\mathrm{Mp}, 2 \mathrm{spB}$ \\
\hline $\begin{array}{l}\text { Spawning requirements (timing, location [river or reservoir], habitat characteristics }{ }^{\mathrm{a}}, \operatorname{cues}^{\mathrm{a}} \text {, impacts of } \\
\text { fluctuating water levels) }\end{array}$ & $\mathrm{Mp}, 2 \mathrm{spB}$ \\
\hline Swimming capacity of various life-stages (to enable assessment of potential instream barriers) & $\mathrm{Mp}_{i} 2 \mathrm{spB}$ \\
\hline Location of potential instream barriers and behaviour of barriers under different flow volumes & Mp \\
\hline Risk, level and timing of cormorant predation & $\mathrm{Mp}$ \\
\hline Will artificial habitat be utilised, and, if so, what are appropriate designs? & $\mathrm{Mp}$ \\
\hline Options for augmentation of fish passage past 'natural' barriers in the river channel & $\mathrm{Mp}$ \\
\hline Expansion of alien fish populations within the reservoir & $\mathrm{Mp}$ \\
\hline Predation by trout on various life-stages (larval, juvenile, sub-adult, adult) in reservoir and river upstream & $\mathrm{Mp}, 2 \mathrm{spB}$ \\
\hline Measures to increase development of fringing macrophytes & $\mathrm{Mp}$ \\
\hline Sedimentation of inundation zone and persistence of fish species & $2 \mathrm{spB}$ \\
\hline Evaluate translocation needs and options (timing, life-stage involved, numbers involved) & $\mathrm{Mp}, 2 \mathrm{spB}$ \\
\hline Susceptibility to EHNV ${ }^{\mathrm{a}}$ & $2 \mathrm{spB}$ \\
\hline $\begin{array}{l}\text { Is EHNV present in existing reservoir, and is there serological evidence that fish have been } \\
\text { exposed to the virus? }\end{array}$ & $\mathrm{Mp}$ \\
\hline Potential impacts of new alien fish (carp and redfin perch) ${ }^{\mathrm{a}}$ & $\mathrm{Mp}, 2 \mathrm{spB}$ \\
\hline Water-quality impacts of inundation (dissolved oxygen, temperature) & $\mathrm{Mp}, 2 \mathrm{spB}$ \\
\hline Effective adult population size of the Cotter Reservoir Macquarie perch population ${ }^{\mathrm{a}}$ & $\mathrm{Mp}$ \\
\hline
\end{tabular}

for the species, developed as part of this program. The translocation program relies predominantly on juvenile fish, as removal of adults may compromise the donor population. To date, $>1000$ fish have been translocated to 3 sites over a 6 yr period, with survival but no recruitment detected at all sites in monitoring from 2009 to 2011. The high fecundity of Macquarie perch (Lintermans 2007) results in substantial numbers of juvenile fish available for translocation. While translocated juvenile fish are expected to have higher natural mortality than would occur with adult fish, the high fecundity of Macquarie perch results in an abundance of juveniles available for translocation. For example, 100 to 450 fish are regularly captured in a single night's netting in the reservoir (author's unpubl. data) and so provide a major option for establishing new populations.

The recommendations from the completed research projects have been used to design and implement management interventions or protocols (Table 4).

Additional mitigation activities that were identified independent of research projects included providing the capacity to mitigate the impacts of expanded reservoir trout populations, utilising the quarry to provide additional fish habitat, reducing the risk of alien fish invasion, providing fish passage at existing anthropogenic barriers, and design and installation of fish-friendly offtake structures (Table 4).

Predation on riverine fish from expanded reservoir trout populations migrating into the river are proposed to be managed with a salmonid trap located immediately upstream of the impounded waters. As spawning migrations for trout (April to August) and Macquarie perch (October to December) are temporally distinct, a trap can be deployed during the trout spawning run with little or no impacts on Macquarie perch movements. The level of salmonid harvest from the trap is yet to be decided, and is dependant on the future government intentions for the small recreational trout fishery upstream of the reservoir. For example, if the fishery is closed, all trout from the trap could be harvested, or, if the fishery is to continue, then only a subset of trout might be harvested.

The quarry established as part of the construction program provides an opportunity to provide substantial refuge habitat for Macquarie perch, particularly during the filling phase before constructed 
Table 3. Research projects aimed to provide knowledge to mitigate the threats and fill critical knowledge gaps outlined in Tables 1 \& 2. Research Institutions - ANU: Australian National University; GU: Griffith University; UC: University of Canberra; USyd: University of Sydney; ARI: Arthur Rylah Institute for Environmental Research; CPR: Conservation, Planning and Research, ACT Government; EE: Ecowise Environmental. EHNV: epizootic haematopoietic necrosis virus

\begin{tabular}{|c|c|c|c|c|}
\hline $\begin{array}{l}\text { Threat no. } \\
\text { addressed }\end{array}$ & Research project & Timeline & $\begin{array}{l}\text { Research } \\
\text { institution }\end{array}$ & Reference \\
\hline $1,2,17$ & $\begin{array}{l}\text { Testing alternate refuge habitat designs and use by } \\
\text { adult Macquarie perch Macquaria australasica }\end{array}$ & $2007-2010$ & $\begin{array}{l}\mathrm{UC}, \mathrm{GU}, \\
\mathrm{CPR}, \mathrm{EE}\end{array}$ & Lintermans et al. (2010) \\
\hline 2 & $\begin{array}{l}\text { Investigating Macquarie perch predation risk } \\
\text { from cormorants }\end{array}$ & $2007-2010$ & UC & Ryan (2010) \\
\hline 3 & $\begin{array}{l}\text { Swimming capacity of Macquarie perch and } \\
\text { alien fish species }\end{array}$ & $2007-2009$ & ANU & $\begin{array}{l}\text { Starrs et al. (2009, } \\
\text { 2011), Starrs (2009) }\end{array}$ \\
\hline 3 & $\begin{array}{l}\text { Investigate remote methods for identification of } \\
\text { potential Macquarie perch migration barriers }\end{array}$ & $2007-2010$ & ANU & Hugh (2010) \\
\hline 3 & $\begin{array}{l}\text { Characterise timing and environmental cues for } \\
\text { Macquarie perch spawning migration }\end{array}$ & $2007-2010$ & $\mathrm{UC}$ & Lintermans et al. (2010) \\
\hline 8 & Survey for EHNV presence in the Cotter catchment & 2008 & USyd, UC & Whittington (2008) \\
\hline $\begin{array}{l}1,2,3,6,9 \\
10,11,15,17\end{array}$ & Long-term fish monitoring program & $\begin{array}{c}\text { 2010-2012 } \\
\text { (Phase 1) }\end{array}$ & $\mathrm{UC}$ & $\begin{array}{l}\text { Lintermans (2009), } \\
\text { Robinson (2010) }\end{array}$ \\
\hline 12 & Food resources for Macquarie perch & $2008-2011$ & $\mathrm{UC}$ & Norris et al. (2011) \\
\hline 14,15 & $\begin{array}{l}\text { Investigating spawning and movement behaviour of } \\
\text { two-spined blackfish Gadopsis bispinosus in an } \\
\text { impoundment }\end{array}$ & $2007-2010$ & $\mathrm{UC}$ & Lintermans et al. (2010) \\
\hline 16 & Water-quality impacts from reservoir inundation & $2010-2011$ & ANU & Bauer (2011) \\
\hline 1,2 & $\begin{array}{l}\text { Characterisation of cormorant predation on } \\
\text { Macquarie perch }\end{array}$ & $2010-2011$ & UC & Lintermans et al. (2011) \\
\hline All & $\begin{array}{l}\text { Investigate translocation options for Macquarie } \\
\text { perch, two-spined blackfish and trout cod }\end{array}$ & $2008-2011$ & $\mathrm{UC}$ & $\begin{array}{l}\text { Bulk Water Alliance } \\
\text { (2010) }\end{array}$ \\
\hline All & $\begin{array}{l}\text { Develop population models to guide translocation } \\
\text { efforts for Macquarie perch and assess likely } \\
\text { impacts of a range of threats for two-spined blackfish }\end{array}$ & $2009-2011$ & UC, ARI & $\begin{array}{l}\text { Bulk Water Alliance } \\
\text { (2010) }\end{array}$ \\
\hline
\end{tabular}

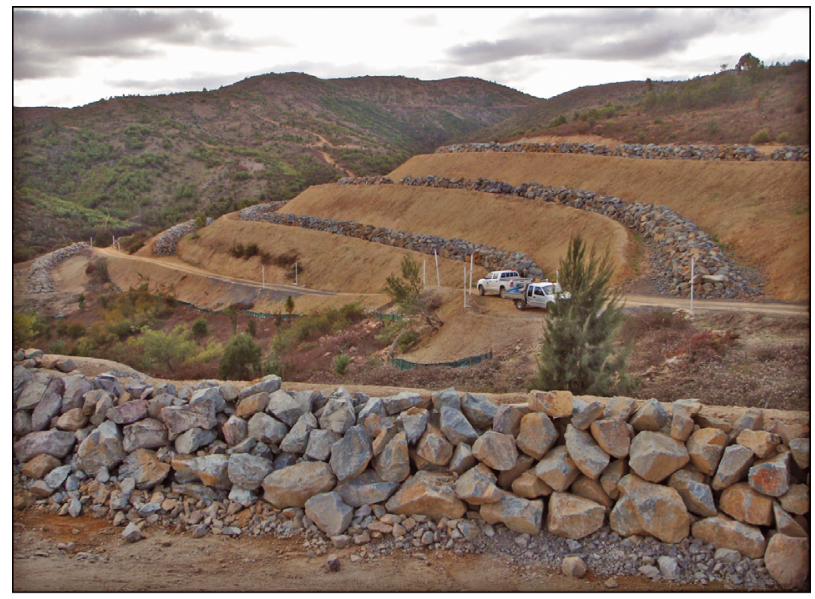

Fig. 3. Rock reef habitats being constructed in the prospective inundation zone of the enlarged reservoir

rock reefs become available to fish. A number of options were explored (e.g. shattering quarry benches and treatment of residual material after quarrying had ceased), but ultimately constructed rock reefs have now been deployed along the spiral access road.

Other mitigation/management measures include the construction of 2 new rockramp fishways at road crossings upstream of the enlarged reservoir that will open up an additional $12.9 \mathrm{~km}$ of riverine habitat for Macquarie perch spawning (ACTEW Corporation 2009). Also, to minimise entrainment of adult and sub-adult Macquarie perch in the reservoir offtake structure, a multilevel intake tower fitted with fish screens has been incorporated into the outlet design of the new dam.

A comprehensive monitoring program has commenced, focussed on 12 hypotheses largely framed around the major potential impacts identified in Table 1. The project commenced in 2010, and will use pre-existing fish distribution and abundance data along with new data to establish a baseline prior to filling. Data will be collected throughout the filling phase and the operational phase, with regular peer review to monitor progress. This long-term project (some elements are mandated to last $20 \mathrm{yr}$ ) will pro- 
Table 4. Management interventions in response to the potential threats outlined in Table 1. EHNV: epizootic haematopoietic necrosis virus

\begin{tabular}{|c|c|}
\hline $\begin{array}{l}\text { Threat no. } \\
\text { addressed }\end{array}$ & Management intervention \\
\hline 1 & Install $\sim 8 \mathrm{~km}$ of fish refuge habitat in response to predicted loss of refuge habitat \\
\hline 1 & $\begin{array}{l}\text { Treatment of quarry (established as part of construction) to provide maximum fish refuge habitat after con- } \\
\text { struction ceases }\end{array}$ \\
\hline 1,17 & Retain, rather than remove, existing structural woody habitat in inundation area \\
\hline 4 & Develop protocol for environmental water releases from Bendora Reservoir \\
\hline $5,13,15$ & $\begin{array}{l}\text { Develop comprehensive environmental management procedures for soil and water quality management and } \\
\text { for emergency and incident response plans }\end{array}$ \\
\hline 8 & $\begin{array}{l}\text { Do not proceed with planned pumping of water from downstream sources into enlarged reservoir (to pre- } \\
\text { vent introduction of EHNV) }\end{array}$ \\
\hline 8 & $\begin{array}{l}\text { Implement EHNV disinfection procedure for all vehicles moving from downstream to upstream of existing } \\
\text { dam wall }\end{array}$ \\
\hline 8 & Develop EHNV response plans \\
\hline 6,8 & $\begin{array}{l}\text { Implement comprehensive carp and redfin perch removal exercise downstream of existing Cotter Dam, and } \\
\text { disinfect construction area (for EHNV) prior to construction of new dam wall }\end{array}$ \\
\hline 7 & $\begin{array}{l}\text { Design and install fish-friendly offtake structures into new dam offtake tower to prevent adult and sub-adult } \\
\text { entrainment }\end{array}$ \\
\hline 10 & $\begin{array}{l}\text { Commit to providing fish passage past } 2 \text { existing anthropogenic fish barriers upstream of Cotter Reservoir to } \\
\text { expand Macquarie perch spawning range. }\end{array}$ \\
\hline 11 & Investigate design and site for location of alien salmonid management trap upstream of Cotter Reservoir \\
\hline 16,18 & Investigate mitigation options to address decreased dissolved oxygen levels after inundation (Loveless 2011) \\
\hline 16 & Modelling of water-quality impacts of flooding terrestrial vegetation (Loveless 2011) \\
\hline All & Production of diverse communication materials to inform the public of issues and progress \\
\hline
\end{tabular}

vide key information on the initial impacts and population responses, as well as the trajectory of fish populations in the long term. It is particularly important to monitor population changes for Macquarie perch as this species is renowned for initial population expansion after reservoir filling, followed by significant population crashes (sometimes to extinction) after 1 to 2 decades (Cadwallader \& Rogan 1977, Lintermans 2006, 2007).

\section{Knowledge management and review mechanisms}

An independent senior fisheries scientist was employed (initially for $5 \mathrm{yr}$ ) to advise on fish issues. A peer review panel of external fish scientists is periodically engaged to provide independent advice, review research project design, progress, and outputs. A stakeholder steering committee was also established containing representation from the Bulk Water Alliance (the constructors of the new dam), the ACTEW Corporation (owners of the dam), state and federal government regulators, and state government fisheries ecologists. For each of the 4 phases of the enlargement process (Fig. 2), a Fish Management Plan (FMP) will be prepared, outlining the threats, risk assessments, knowledge gap review, and threat mitigation measures to be implemented. To date, Versions 1 (Nagy et al. 2008) and 2 (Bulk Water Alliance 2010) have been prepared (Fig. 2).

There has been considerable effort devoted to disseminating knowledge generated from the Cotter fish research program, with in excess of 35 presentations to date delivered at local, national, and international science and management forums since 2008. Publication in the peer-reviewed literature is also being pursued as projects are completed. Numerous pamphlets, flyers, and video outputs have also been produced, and innovative dissemination via YouTube has also been explored (www.youtube.com/watch? $\mathrm{v}=\mathrm{V} 3 \mathrm{GxT}$ 10-Ds and www.youtube.com/watch? $\mathrm{v}=\mathrm{b}$ HFSNB43cr8).

The enlargement of Cotter Reservoir could provide some benefits to the 2 threatened fish species. The anticipated trophic upsurge is likely to result in an increased abundance and body condition of Macquarie perch, potentially allowing increased harvest of individuals to facilitate establishment of additional populations through translocation. Both threatened fish species will have a much higher public profile as a result of the construction and research activities, and the benefits of improved 
ecological knowledge for both species will be transferrable throughout much of their geographic range. The construction of fishways past existing anthropogenic barriers in the lower Cotter River is unlikely to have occurred without the resources provided as a result of reservoir enlargement. An enlarged reservoir will drown-out some existing natural movement barriers (small cascades and rock bars) for Macquarie perch that are currently limiting upstream movement from Cotter Reservoir. This will potentially improve access to upstream spawning habitat (in conjunction with fishway construction). Finally, the knowledge generated from individual projects (e.g. constructed habitats) could be transferred to other infrastructure projects that may impact freshwater fish. The fish program associated with the enlarged Cotter Reservoir is the most comprehensive effort ever conducted to identify and mitigate the impacts of a single piece of water infrastructure on threatened species in Australia, and provides a model for Australian and international infrastructure projects.

\section{Benefits of comprehensive and collaborative approach}

Management of the aquatic ecosystems of the Cotter River has a strong history of science-based management and collaborative approaches between research institutions, government, and water utilities (e.g. Norris \& Nichols 2011), and the collaborative approach demonstrated in the enlargement of Cotter Reservoir is another example. Rather than adopt an adversarial approach, the water utility and design and construction alliance have actively engaged with and invested in the science. The benefits of this approach are likely to flow beyond the Cotter system as future water infrastructure development will undoubtedly interact with threatened aquatic species in the future. The established long-standing good working relationships with all key stakeholders fosters trust and good faith, allowing researchers, managers, and regulators to achieve outcomes beyond that achievable through purely legislative approaches (Poff et al. 2003). The use of independent science providers and independent peer review provides transparency and comfort to regulators and governing bodies, with an active stakeholder steering committee capable of identifying potential issues earlier rather than later. The use of a range of science providers provides the capacity to access cutting-edge science from a variety of disciplines, rather than relying on the inhouse capacity and potentially dated knowledge. An in-house science advisor is dedicated to guiding the process and preventing the development of flawed approaches, and an in-house fish management team within the water utility provides the interface for and integrates science, design, and construction issues.

\section{Challenges}

Aquatic ecosystems are complex and variable, and, as a consequence, there are still challenges that have arisen within the enlarged Cotter Reservoir process. Most challenges relate to short timelines, sub-optimal communication between managers, researchers, and constructors, and changing design, construction, and management priorities during the project. Cost pressures to bring a project in on-time and on-budget can result in conflict over the time required to develop sound, science-based advice. For example, changing priorities, construction scenarios, or construction sequencing in response to uncontrollable climatic events (e.g. flooding) can result in insufficient time to collect rigorous ecological data to inform management questions. The highly variable nature of natural ecosystems and the time required to collect robust data which capture seasonal or annual variation is also an irritant to constructing authorities, and so ecologists are often expected to extrapolate from the data of a single season or year. While the early identification of potential threats was beneficial, the 2 yr delay in deciding which preferred water supply option to proceed with was unfortunate, resulting in lost opportunities for gathering data over multiple years.

The inevitable occasional clash of culture between science, construction, and management requires considerable diplomacy at times. If collaborative relationships are to be maintained, mutual respect and understanding are crucial, as opposed to the standard legislative/permissions approach. However, access to independent peer review (an impartial umpire) is crucial to both resolving such conflicts and making sure that any 'in-house' solutions are exposed to external critical review. Securing a long-term investment (on an ecological timescale) to monitoring and adaptive management can be difficult. Most funding commitments for monitoring are of short duration (usually $<5 \mathrm{yr}$ ); however, the monitoring program for the enlarged Cotter Reservoir extends throughout the 
construction (baseline), filling, and operational phases, with some elements mandated to continue for $20 \mathrm{yr}$.

Finally, ensuring that fish conservation benefits are considered a primary value of some reservoirs (rather than just an add-on bonus to water supply or flood mitigation) requires a significant mindset change by many water authorities. This change of mindset has occurred with the current water utility, and has been facilitated by the knowledge generation and management process outlined in the present paper. Reservoirs may become increasingly important refugia for threatened species as degradation of riverine habitats continues. In Australia several threatened freshwater species attain substantial population sizes in reservoirs or anthropogenically altered lakes (Cadwallader \& Rogan 1977, Douglas 2002, Hardie et al. 2007, Hammer et al. 2009, Ebner et al. 2011). The presence of significant populations of threatened fish highlights the need to value reservoir populations of threatened species and consider reservoir populations when planning conservation programs. However, once their conservation benefits are recognised, water authorities can be powerful and enthusiastic partners in fish conservation programs. This project demonstrates how collaboration between water utilities, scientists, and regulators can effectively meet these challenges. The importance of strong state/provincial and federal legislation on threatened species should not be underestimated either, as these statutes and their development approval processes were the drivers for the research and mitigation process.

\section{CONCLUSIONS}

The enlargement of Cotter Reservoir poses a number of significant threats to Macquarie perch and two-spined blackfish, with most of the threats in and upstream of the inundation area. The early identification of potential impacts allowed the development of a collaborative and comprehensive research and management program which has facilitated the development and evaluation of a variety of mitigation measures. All of the major risks have been addressed, and appropriate mitigation measures have been implemented. The establishment of an independent, collaborative, science-driven process, coupled with the establishment of a long-term monitoring program in an adaptive management framework is a model for other infrastructure projects worldwide.
Acknowledgements. The present study is dedicated to Emeritus Professor Richard Norris, an inspirational freshwater scientist and mentor. I thank ACTEW Corporation and the Bulk Water Alliance (a consortium of Abigroup, ACTEW Corporation, GHD and John Holland) for funding the research and management programs associated with the enlarged Cotter Reservoir. Laslo Nagy (ActewAGL), Brigitte Kuhn, Ray Hezkial, and Ray Sloan (Bulk Water Alliance), and Chris Webb (ACTEW Corporation) facilitated, coordinated, and managed the fish program for the enlarged Cotter Reservoir. Richard Norris paved the way for the fish science program at the University of Canberra, and numerous collaborators in the fish program have shared their results and knowledge with me, in particular (in alphabetical order) Matt Beitzel, Ben Broadhurst, Rhian Clear, Brendan Ebner, Lisa Evans, Chris Fulton, Norm Mueller, Katie Ryan, Dan Starrs, Ty Starrs, Jason Thiem, Charles Todd, Richard Whittington, and Danny Wright. John Koehn, John Harris, and Alistair Cameron have provided independent peer reviews throughout the program, which has greatly strengthened the science. Ben Broadhurst and Brigitte Kuhn kindly provided comments on this manuscript. All research has been conducted in accordance with institutional and national guidelines concerning the use of animals in research and the sampling of threatened species.

\section{LITERATURE CITED}

ACTEW Corporation (2009) Enlargement of the Cotter Reservoir and associated works. Final public environment report 2008/4524. ACTEW Corporation, Canberra. Available at: www.actew.com.au/WaterSecurity/News/enlarged_ cotter_dam.aspx\#PER (accessed on 18 May 2011)

Agostinho AA, Pelicice FM, Gomes LC (2008) Dams and the fish fauna of the Neotropical region: impacts and management related to diversity and fisheries. Braz J Biol 68: $1119-1132$

Allen GR, Midgley SH, Allen M (2002) Field guide to the freshwater fishes of Australia. Western Australian Museum, Perth

Bauer B (2011) Organic matter and dissolved oxygen in the enlarged Cotter Dam. BPhil (Hons) dissertation, Australian National University, Canberra

- Baxter RM (1977) Environmental effects of dams and impoundments. Annu Rev Ecol Syst 8:255-283

BOM (Bureau of Meteorology) (2011) Monthly mean and maximum temperatures for station 70316, Tidbinbilla Nature Reserve. BOM, Canberra. Available at: www. bom.gov.au/climate/ (accessed on 15 August 2011)

Bond NR, Lake PS, Arthington AH (2008) The impacts of drought on freshwater ecosystems: an Australian perspective. Hydrobiologia 600:3-16

Broadhurst BT, Dyer JG, Ebner BC, Thiem JD, Pridmore PA (2011) Response of two-spined blackfish Gadopsis bispinosus to short-term flow fluctuations in an upland Australian stream. Hydrobiologia 673:63-77

Bulk Water Alliance (2010) Enlarged Cotter Dam fish management plan, version two. Bulk Water Alliance, Canberra. Available at: www.actew.com.au/publications/ ECD_Fish_Management_Plan_V2.pdf (accessed on 4 May 2011)

Cadwallader PL (1978) Some causes of the decline in range and abundance of native fish in the Murray-Darling River system. Proc R Soc Vic 90:211-224 
Cadwallader PL (1986) The Macquarie perch of Lake Dartmouth. Aust Fish 45:14-16

Cadwallader PL (1996) Overview of the impacts of introduced salmonids on Australian native fauna. Australian Nature Conservation Agency, Canberra. Available at: www.environment.gov.au/biodiversity/invasive/publications/pubs/salmonids.pdf (accessed on 15 May 2011)

> Cadwallader PL, Rogan PL (1977) The Macquarie perch Macquaria australasica (Pisces: Percichthyidae), of Lake Eildon, Victoria. Aust J Ecol 2:409-418

Cambray JA (2003) The global impact of alien trout species-a review; with reference to their impact in South Africa. Afr J Aquat Sci 28:61-67

Carey A, Evans M, Hann P, Lintermans M and others (2003) Wildfires in the ACT 2003: report on initial impacts on natural ecosystems. Tech Rep No. 17, Environment ACT, Canberra

- Clavero M, Blanco-Garrido F, Prenda J (2004) Fish fauna in Iberian Mediterranean river basins: biodiversity, introduced species and damming impacts. Aquat Conserv 14: $575-585$

Cowx IG (2002) Analysis of threats to freshwater fish conservation: past and present challenges. In: Collares-Pereira MJ, Cowx IG, Coelho MM (eds) Conservation of freshwater fishes: options for the future. Fishing News Books, Oxford, p 201-236

CSIRO, Bureau of Meteorology (2007) Climate change in Australia: technical report. CSIRO, Aspendale, Victoria

Davies PE, Harris JH, Hillman TJ, Walker KF (2010) The sustainable rivers audit: assessing river ecosystem health in the Murray-Darling Basin, Australia. Mar Freshw Res 61:764-777

Douglas J (2002) Observations on aspects of Macquarie perch Macquaria australasica (Cuvier) spawning natural recruitment and selected population attributes in Lake Dartmouth and the Mitta Mitta River between 1994 and 1998. Freshwater Fisheries Rep No. 02/07, Marine and Freshwater Resources Institute, Department of Natural Resources and Environment, Melbourne

> Dudgeon D, Arthington AH, Gessner MO, Kawabata Z and others (2006) Freshwater biodiversity: importance, threats, status and conservation challenges. Biol Rev Camb Philos Soc 81:163-182

Ebner B, Lintermans M (2007) Fish passage, movement requirements and habitat use for Macquarie perch. Final report to the Department of Agriculture, Fisheries and Forestry Australia, Parks, Conservation and Lands, Canberra

Ebner B, Broadhurst B, Lintermans M, Jekabsons M (2007) A possible false negative: lack of evidence for trout predation on a remnant population of the endangered Macquarie perch, Macquaria australasica, in Cotter Reservoir, Australia. NZ J Mar Freshw Res 41:231-237

Ebner BC, Lintermans M, Dunford M (2011) A reservoir serves as refuge for adults of the endangered Macquarie perch. Lakes Reservoirs: Res Manage 16:23-33

Farrington LW, Lintermans M, Ebner BC (2009) Characterising genetic diversity in the nationally threatened fish Macquarie perch, Macquaria australasica in the upper Murrumbidgee River. Final Report for the Natural Heritage Trust Project No. 18152

Faulks LK, Gilligan DM, Beheregaray LB (2010) Evolution and maintenance of divergent lineages in an endangered freshwater fish, Macquaria australasica. Conserv Genet 11:921-934
Ficke AD, Myrick CA, Hansen LJ (2007) Potential impacts of global climate change on freshwater fisheries. Rev Fish Biol Fish 17:581-613

> Gao X, Zeng Y, Wang J, Liu H (2010) Immediate impacts of the second impoundment on fish communities in the Three Gorges Reservoir. Environ Biol Fishes 87:163-173

> Gehrke PC, Gilligan DM, Barwick M (2002) Changes in fish communities of the Shoalhaven River 20 years after construction of Tallowa Dam, Australia. River Res Appl 18: 265-286

Government ACT (2007) Ribbons of life: ACT aquatic species and riparian zone conservation strategy. Action Plan No. 29, Arts Heritage and Environment, Canberra

Graf WL (2001) Damage control: restoring the physical integrity of America's rivers. Ann Assoc Am Geogr 91: $1-17$

> Gunkel G, Lange U, Walde D, Rosa JWC (2003) The environmental and operational impacts of Curuá-Una, a reservoir in the Amazon region of Pará, Brazil. Lakes Reservoirs: Res Manage 8:201-216

Halverson MA (2010) An entirely synthetic fish: how rainbow trout beguiled America and overran the world. Yale University Press, New Haven, CT

Hammer M, Wedderburn S, Van Weenen J (2009) Action plan for South Australian freshwater fishes. Native Fish Australia (SA), Adelaide

Hardie SA, White RWG, Barmuta LA (2007) Reproductive biology of the threatened golden galaxias Galaxias auratus Johnston and the influence of lake hydrology. J Fish Biol 71:1820-1840

Havel JE, Lee CE, Vander Zanden MJ (2005) Do reservoirs facilitate invasions into landscapes? Bioscience 55:518-525

Helfman S (2007) Fish conservation: a guide to understanding and restoring global aquatic biodiversity and fishery resources. Island Press, Washington, DC

Hugh S (2010) Predicting barriers to the movement of Macquarie perch (Macquaria australasica). MPhil dissertation, Australian National University, Canberra

Jelks HL, Walsh SJ, Burkhead NM, Contreras-Balderas S and others (2008) Conservation status of Imperiled North American freshwater and diadromous fishes. Fisheries 33:372-407

> Johnson PT, Olden JD, Vander Zanden MJ (2008) Dam invaders: impoundments facilitate biological invasions into freshwaters. Front Ecol Environ 6:357-363

> Juncos R, Milano D, Macchi PJ, Alonso MF, Vigliano PH (2011) Response of rainbow trout to different food web structures in northern Patagonia: implications for growth, bioenergetics, and invasiveness. Trans Am Fish Soc 140:415-428

Kimmel BL, Groeger AW (1986) Limnological and ecological changes associated with reservoir aging. In: Hall GE, Van Den Avyle MJ (eds) Reservoir fisheries management: strategies for the 80's. Reservoir Committee, Southern Division American Fisheries Society, Bethesda, MD, p 103-109

King AJ, Tonkin Z, Mahoney J (2009) Environmental flows enhance native fish spawning and recruitment in the Murray River, Australia. River Res Appl 25:1205-1218

Koehn JD (1990) Distribution and conservation status of the two-spined blackfish, Gadopsis bispinosus, in Victoria. Proc R Soc Vic 102:97-103

Koehn JD, Lintermans M (in press) A strategy to rehabilitate fishes of the Murray-Darling Basin, south-eastern Australia. Endang Species Res doi:10.3354/esr00398 
Langdon JS (1989) Experimental transmission and pathogenicity of epizootic haematopoietic necrosis virus (EHNV) in redfin perch Perca fluviatilis L., and 11 other teleosts. J Fish Dis 12:295-310

Langdon JS, Humphrey JD (1987) Epizootic haematopoietic necrosis, a new viral disease in redfin perch Perca fluviatilis L., in Australia. J Fish Dis 10:289-297

Langdon JS, Humphrey JD, Williams LM, Hyatt AD, Westbury HA (1986) First virus isolation from Australian fish: an iridovirus-like pathogen from redfin perch Perca fluviatilis L. J Fish Dis 9:129-135

Larinier M (2001) Environmental issues, dams and fish. In: Marmulla G (ed) Dams, fish and fisheries. Opportunities, challenges and conflict resolution. FAO Fisheries Technical Paper No. 419, FAO, Rome, p 45-90

Lintermans M (1998) The ecology of the two-spined blackfish Gadopsis bispinosus (Pisces: Gadopsidae). MSc dissertation, Australian National University, Canberra

Lintermans M (2002) Fish in the Upper Murrumbidgee Catchment: a review of current knowledge. Environment ACT, Canberra

Lintermans M (2006) The re-establishment of the endangered Macquarie perch, Macquaria australasica, in the Queanbeyan River, New South Wales, with an examination of dietary overlap with alien trout. CRC Freshwater Ecology Technical Report. Available at: http://freshwater. canberra.edu.au/publications.nsf/60da502789f083dbca 256ee40022a54e/9ffa733471131b0aca25725f00244a04? OpenDocument (accessed on 18 May 2011)

Lintermans M (2007) Fishes of the Murray-Darling Basin: an introductory guide. Murray-Darling Basin Commission, Canberra

Lintermans M (2009) Scope of monitoring required for the enlarged Cotter Dam (ECD). Report to the Bulk Water Alliance, Institute for Applied Ecology, University of Canberra

Lintermans M, Ebner B (2010) Threatened fish profile: 'western' Macquarie perch Macquaria australasica Cuvier, 1830. Aust Soc Fish Biol Newsl 40:76-78

Lintermans M, Rutzou T (1991) The status, distribution and management of the Murray crayfish Euastacus armatus in the Australian Capital Territory. Res Rep 6, ACT Parks and Conservation Service, Canberra

Lintermans M, Broadhurst B, Thiem JD, Ebner BC, Wright D, Clear R, Norris RH (2010) Constructed homes for threatened fishes in the Cotter River catchment: Phase 2 final report. Report to ACTEW Corporation, Institute for Applied Ecology, University of Canberra

Lintermans M, Broadhurst B, Clear R (2011) Characterising potential predation of Macquarie perch Macquaria australasica by cormorants in Cotter Reservoir. Institute for Applied Ecology, University of Canberra

Loveless A (2011) Modelling dissolved oxygen dynamics in the enlarged Cotter Reservoir, ACT. Report to ACTEW Corporation, Hydronumerics, Carlton

- Maddock A, Thoms M, Jonson K, Dyer F, Lintermans M (2004) Identifying the influence of channel morphology on physical habitat availability for native fish: application to the two-spined blackfish (Gadopsis bispinosus) in the Cotter River, Australia. Mar Freshw Res 55: 173-184

Malmqvist B, Rundle S (2002) Threats to the running water ecosystems of the world. Environ Conserv 29:134-153

McDowall RM (2006) Crying wolf, crying foul, or crying shame: alien salmonids and a biodiversity crisis in the southern cool-temperate galaxioid fishes? Rev Fish Biol Fish 16:233-422

McKeown KC (1944) The food of cormorants and other fisheating birds. Emu 43:259-269

MDBA (Murray-Darling Basin Authority) (2010) Guide to the proposed basin plan: overview. MDBA, Canberra

> Miller B (1979) Ecology of the little black cormorant Phalacrocorax sulcirostris and little pied cormorant $P$. melanoleucos, in inland New South Wales. I. Food and feeding habits. Aust Wildl Res 6:79-95

Morris SA, Pollard, DA, Gehrke PC, Pogonoski JJ (2001) Threatened and potentially threatened freshwater fishes of coastal New South Wales and the Murray-Darling Basin. Report to Fisheries Action Program and World Wide Fund for Nature, NSW Fisheries Final Report Series No. 33, NSW Fisheries, Sydney

Nagy L, Brunner L, Elliott K, Lintermans M (2008) Enlarged Cotter Dam fish management plan (version 1). ACTEW Corporation, Canberra

> Nichols S, Norris R, Maher W, Thoms M (2006) Ecological effects of serial impoundment on the Cotter River, Australia. Hydrobiologia 572:255-273

Nilsson C, Reidy CA, Dynesius M, Revenga C (2005) Fragmentation and flow regulation of the world's large river systems. Science 308:405-408

Norris R, Nichols S (2011) Environmental flows: achieving ecological outcomes in variable environments. In: Grafton RQ, Hussey K (eds) Water resources planning and management. Cambridge University Press, Cambridge, p 331-349

Norris RH, Wright DW, Lintermans M, Bourke DF, Harrison ET (2011) Food resources for Macquarie perch in Cotter Reservoir. Report to ACTEW Corporation, Institute for Applied Ecology, University of Canberra

O'Connor JP, Zampatti BP (2006) Spawning season and site location of Gadopsis bispinosus Sanger (Pisces: Gadopsidae) in a montane stream of southeastern Australia. Trans R Soc S Aust 130:227-232

Olden JD, Naiman RJ (2010) Incorporating thermal regimes into environmental flows assessments: modifying dam operations to restore freshwater ecosystem integrity. Freshw Biol 55:86-107

> Palmer MA, Reidy Liermann CA, Nilsson C, Flörke M, Alcamo J, Lake PS, Bond NR (2008) Climate change and the world's river basins: anticipating management options. Front Ecol Environ 6:81-89

Pittock J, Hartmann J (2011) Taking a second look: climate change, periodic relicensing and improved management of dams. Mar Freshw Res 62:312-320

Poff NL, Allan JD, Palmer MA, Hart DD and others (2003) River flows and water wars: emerging science for environmental decision making. Front Ecol Environ 1: 298-306

Poff NL, Olden JD, Merritt DM, Pepin DM (2007) Homogenization of regional river dynamics by dams and global biodiversity implications. Proc Natl Acad Sci USA 104: 5732-5737

Poff NL, Richter BD, Arthington AH, Bunn SE and others (2010) The ecological limits of hydrologic alteration (ELOHA): a new framework for developing regional environmental flow standards. Freshw Biol 55:147-170

Popp A, Hoagland K, Hergenrader G (1996) Zooplankton community response to reservoir aging. Hydrobiologia 339:13-21

Prenda J, Clavero M, Blanco-Garrido F, Menor A, Hermosa 
V (2006) Threats to the conservation of biotic integrity in Iberian fluvial ecosystems. Limnética 25:377-388

Robinson W (2010) Statistical power of monitoring program (Macquarie perch). Consultancy report to the Bulk Water Alliance, University of the Sunshine Coast, Maroochydore

Ryan KA (2010) Macquarie perch under pressure: predation risk to an endangered fish population. PhD dissertation, Institute for Applied Ecology, University of Canberra, Canberra

Sala OE, Chapin FS III, Armesto JJ, Berlow E and others (2000) Global biodiversity scenarios for the year 2010. Science 287:1770-1774

Sherman B, Todd CR, Koehn JD, Ryan T (2007) Modelling the impact and potential mitigation of cold water pollution on Murray cod populations downstream of Hume Dam, Australia. River Res Appl 23:377-389

St. Louis VL, Kelly CA, Duchemin E, Rudd JWM, Rosenberg DM (2000) Reservoir surfaces as sources of greenhouse gases to the atmosphere: a global estimate. Bioscience 50:766-775

Starrs T (2009) Swimming performance as a measure of exotic fish invasion risk in the Cotter River, ACT. BSc (Hons) dissertation, Australian National University, Canberra

Starrs D, Fulton C, Starrs T (2009) Predicted passage of native and alien freshwater fish in the Cotter River, ACT using measures of swimming speed performance. Report to ACTEW, Research School of Biology, Australian National University, Canberra

Editorial responsibility: Steven Cooke, Ottawa, Ontario, Canada
Starrs D, Ebner BC, Lintermans M, Fulton CJ (2011) Using sprint swimming performance to predict upstream passage of the endangered Macquarie perch in a highly regulated river. Fish Manag Ecol 18:360-374

Tonkin Z, Lyon J, Pickworth A (2010) Spawning behaviour of the endangered Macquarie perch Macquaria australasica in an upland Australian river. Ecol Manage Restor 11:223-226

TSS (Threatened Species Section) (2006) Recovery Plan: Tasmanian Galaxiidae 2006-2010. Threatened Species Section, Department of Primary TSS

Wharton JCF (1968) Spawning areas of the Macquarie perch Macquaria australasica above the Eildon Lake (Victoria). Aust Soc Limnol Newsl 6:11-13

Whittington RJ (2008) Testing for epizootic haematopoietic necrosis virus, Cotter Dam. Report to ACTEW Corporation, Faculty of Veterinary Science, University of Sydney

Whittington RJ, Kearns C, Hyatt AD, Hengstberger S, Rutzou T (1996) Spread of epizootic haematopoietic necrosis virus in southern Australia. Aust Vet J 73:112-114

Whittington R, Becker J, Tweedie A, Gilligan D, Asmus M (2010) Susceptibility of previously untested basin fish species to epizootic haematopoietic necrosis virus (EHNV) and its epidemiology in the wild. Report to Murray-Darling Basin Authority on Project No. MD743, University of Sydney

Wootton RJ (1998) Ecology of teleost fishes, 2nd edn. Kluwer Academic Publications, London

Submitted: May 31, 2011; Accepted: September 12, 2011 Proofs received from author(s): December 1, 2011 